\title{
CYTOHISTOLOGICAL STUDY OF SALIVARY GLAND LESIONS
}

\author{
Subhashini Bandar1, Kanchana Priyadarshini V. N2, Indira Avanigadda3, Srinitisha Hanumanthu4, P. V. B. Ramalaxmi ${ }^{5}$
}

${ }^{1}$ Assistant Professor, Department of Pathology, Kamineni Institute of Medical Sciences, Narketpally, Nalgonda District, Telangana. ${ }^{2}$ Assistant Professor, Department of Pathology, Maharajah's Institute of Medical Sciences, Nellimarla, Vizianagaram, A. P.

${ }^{3}$ Final Year Postgraduate Student, Department of Pathology, Maharajah's Institute of Medical Sciences, Nellimarla, Vizianagaram, A. P. ${ }^{4}$ Final Year Postgraduate Student, Department of Pathology, Maharajah's Institute of Medical Sciences, Nellimarla, Vizianagaram, A. P. ${ }^{5}$ Professor and HOD, Department of Pathology, Maharajah's Institute of Medical Sciences, Nellimarla, Vizianagaram, A. P.

ABSTRACT
BACKGROUND
Salivary gland lesions are one of the palpable lesions subjected for Fine Needle Aspiration Cytology (FNAC) for diagnosis.
Preoperative diagnosis helps in selection of appropriate treatment in every case.
The aim of present study is to examine the cytological features of salivary gland lesions in aspirated smears and to evaluate the
efficacy of FNAC in correlation with histopathological diagnosis in salivary gland lesions.

\section{MATERIALS AND METHODS}

The study includes 52 patients with salivary gland lesions who came for FNAC, of which for 34 cases surgical specimens were received for Histopathological Examination (HPE). Diagnostic accuracy was studied by statistical analysis.

\section{RESULTS}

In this study of 34 cases of correlation, maximum cases were obtained for pleomorphic adenoma making it the commonest benign tumour followed by malignancy. Parotid gland was the most common site involved in salivary gland lesions. FNAC diagnosis was consistent with HPE in 30 cases and inconsistent in 4 cases.

\section{CONCLUSION}

FNAC is a highly reliable technique for pre-operative diagnosis of salivary gland tumours in the hands of experienced pathologists. Due to the minimally invasive nature of this technique, FNAC offers valuable information for planning of subsequent therapeutic management.

\section{KEYWORDS}

FNAC, Salivary Gland Lesions, HPE.

HOW TO CITE THIS ARTICLE: Bandar S, Priyadarshini KVN, Avanigadda I, et al. Cytohistological study of salivary gland lesions. J. Evolution Med. Dent. Sci. 2016;5(103):7571-7576, DOI: 10.14260/jemds/2016/1714

\section{BACKGROUND}

FNAC is useful in the diagnosis of salivary gland lesions and often influences management of the patient and allows for appropriate treatment planning. Non-neoplastic lesions can be distinguished from neoplastic and benign tumours from malignant ones. The complications of the FNAC are rare, making it one of the popular diagnostic tool. In this study the cytological spectrum of salivary gland lesions studied, HPE correlation was done for available cases. Statistical analysis like sensitivity, specificity and diagnostic accuracy was done.

The results compared with other studies substantiate the findings of the series and affirms the usefulness of FNAC as a simple, cost effective and minimally invasive diagnostic tool in the evaluation of salivary gland lesions.

Financial or Other, Competing Interest: None.

Submission 19-11-2016, Peer Review 12-12-2016,

Acceptance 19-12-2016, Published 26-12-2016.

Corresponding Author:

Dr. Kanchana Priyadarshini V. N,

Assistant Professor,

Department of Pathology,

MIMS, Nellimarla-535217,

Vizianagaram District,

Andhra Pradesh.

E-mail: kanpras@gmail.com

DOI: $10.14260 /$ jemds $/ 2016 / 1714$

\section{(c) $(1)(5)$}

\section{MATERIALS AND METHODS}

The present study includes aspiration smears of lesions from both major and minor salivary glands. These cases were referred to the cytology lab in the Department of Pathology. The study includes 52 cases of aspiration smears of which for 34 cases surgical specimens were received for HPE. After taking consent and relevant history, FNAC was done after local examination. Smears were stained with Haematoxylin and Eosin. Surgical specimens were examined, sections were given from representative area, processed and stained with Haematoxylin and Eosin.

\section{RESULTS}

In the present study conducted from June 2010 - June 2014, 52 aspirations were performed on patients with salivary gland lesions. Among them 34 patients underwent surgery and were followed by histopathological diagnosis. These 34 cases were considered for cytological and histopathological correlation and calculating the diagnostic accuracy.

In the present study, age group of the patients ranged from 12 - 75 years. Maximum number of patients, 38 (73.08\%) belonged to age group between 21 - 50 years. Female distribution is $28(53.85 \%)$ and male distribution is 24 (46.15\%). Age and sex distribution among the cases is shown in [Table 1]. The study showed salivary gland lesions were more common on the right side compared to the left side and more common on the right parotid gland 21 (40.38\%) compared to the left parotid gland 14 (26.92\%). In the present 
study, salivary gland lesions are classified into three diagnostic classes as non-neoplastic lesions 4 (7.69\%), benign lesions 43 (82.69\%) and malignant lesions 5 (9.62\%). Categorisation of salivary gland lesions are shown in [Table 2]. Salivary gland lesions were more common in the age group of 21 - 50 years constituting 38 cases (73.07\%). Non-neoplastic lesions were common in the age group of 21 - 30 years constituting 3 cases (75\%). Benign lesions were common in 21 - 50 years constituting 34 cases (74.42\%). Malignant lesions were common in the age group of 61 - 70 years constituting $3(60 \%)$. Among the non-neoplastic lesions, chronic sialadenitis was most common comprising of 4 cases; 2 cases were seen in the parotid gland and 1 case was seen in the submandibular gland and 1 case in sublingual gland respectively and were common in the age group of 21 - 30 years. In this study among the benign neoplastic lesions, pleomorphic adenoma was the most common lesion comprising of 36 cases $(83.72 \%)$ which was seen most common in the parotid gland. Two cases of benign cystic lesions were seen. One case each of Warthin's tumour, oncocytoma, benign myoepithelioma and basal cell adenoma was seen in the parotid gland. Cytodiagnosis of benign neoplastic salivary gland lesions are shown in [Table 3].

In the present study among the malignant neoplastic lesions of salivary glands, 2 cases of adenoid cystic carcinoma $(40 \%)$ were noted - one case was seen in the parotid gland and one more case was seen in minor salivary gland.

One case of mucoepidermoid carcinoma was seen in the submandibular gland (20\%). One case of epithelialmyoepithelial carcinoma was seen in the parotid gland (20\%). One case of squamous cell carcinoma was seen in parotid gland (20\%). Cytodiagnosis of malignant salivary gland lesions is shown in [Table 4].

Among 52 aspirations, 34 patients underwent surgery and were followed by histopathological diagnosis. Histopathological correlation of salivary gland lesions (34 cases) is shown in [Table 5]. In the present study among 4 cases of chronic sialadenitis on cytology, 2 cases were correlated with histopathology and 2 cases were diagnosed as pleomorphic adenoma on histopathology. This may be due to needle entering the area adjacent to the tumour. Microscopy of chronic sialadenitis is shown in [Figure 1].

In the present study 21 cases of pleomorphic adenoma were correlated well; 2 cases of benign cystic lesion on cytology were diagnosed as pleomorphic adenoma on histopathology. This may be due to scant cellularity and abundant necrotic material. In the present study, all 5 malignant neoplastic lesions on cytology were correlated well with histopathology. The diagnostic accuracy of the present study is shown in [Table 6]. The sensitivity of present study is $87.50 \%$, specificity is $100 \%$ and diagnostic accuracy is $88.24 \%$.

\section{DISCUSSION}

The present study is a retrospective and prospective study performed over a period of four years from June 2010 to June 2014. During this 52 FNAC's were obtained from patients with salivary gland lesions. Among them 34 cases underwent surgery. These cases were followed up by histopathological confirmation. For these cases, cytohistopathological correlation was done for calculating their diagnostic accuracy.
The age of the patients ranged from 12 to 75 years. The oldest case (75 years) and youngest (12 years) maximum number of patients belonged to the age group of 31 - 40 yrs. $(70.08 \%)$ with more in females $(53.85 \%)$ than males $(46.15 \%)$. There is a female preponderance in the distribution of salivary gland lesions, which is comparable with the studies done by Kasangaki et $\mathrm{al}^{1}$ and Thomas et $\mathrm{al}^{2}$ In the present study, salivary gland lesions are more common in the major salivary glands compared to the minor salivary glands. In the major salivary glands, parotid gland is the most common site followed by submandibular gland and sublingual gland is less common site. This is comparable with the studies done by Gupta et $\mathrm{al}^{3}$ Ahrnad et $\mathrm{al}^{4}$ and Krishnarai Subhashraj et al. ${ }^{5}$ [Table 7] Shows age distribution (Average age in years) of benign and malignant salivary gland lesions of various studies. In the present study among 4 cases of chronic sialadenitis on cytology, 2 cases were correlated with histopathology and 2 cases were diagnosed as pleomorphic adenoma on histopathology. This may be due to needle entering the area adjacent to the tumour.

In the present study, benign tumours occur at a lower age group compared with the malignant tumours which is almost comparable with the studies done by Agarwal et al $^{6}$ and Vuhahula et al. ${ }^{7}$ Benign lesions are more common than the malignant lesions, which is almost comparable with the studies done by Seth. ${ }^{8}$ In the present study, pleomorphic adenoma was the common benign tumour accounting for $73.08 \%$ of all total tumours and $86.05 \%$ of all benign tumours which is comparable with the studies done by Ahrnad et $\mathrm{al}^{4}$ and Davies et al. ${ }^{9}$

In the present study parotid gland was the most common site of pleomorphic adenoma followed by submandibular gland, which is comparable with the studies done by Itoh et al ${ }^{10}$ and Nagarkar et al. ${ }^{11}$

Among the 34 cases of pleomorphic adenoma diagnosed on FNAC, 21 cases were available for cytohistological correlation. In the present study, 21 cases of pleomorphic adenoma were correlated well; 2 cases of benign cystic lesion on cytology were diagnosed as pleomorphic adenoma on histopathology. This may be due to scant cellularity and abundant necrotic material.

In the present study, all 5 malignant neoplastic lesions on cytology were correlated well with histopathology. Pleomorphic adenoma cytological features showed fibrillary chondromyxoid ground substance admixed with epithelial cells arranged singly and in poorly cohesive clusters. This is shown in [Figure 2]. One case showed tyrosine crystals on cytology; 23 cases of pleomorphic adenoma were seen in the present study. Gross features showed irregular to globular shaped masses, firm in consistency. Cut section showed greywhite homogeneous solid areas with focal blue translucent areas in some tumours. Microscopy showed epithelial and myoepithelial cells arranged in various patterns. Few cases showed chondromyxoid areas. Few cases showed squamous metaplasia with epithelial pearl formation [Figure 3]. Few cases showed cystic change. Similar observations were made by studies done by Evans and Cruickshank,12 Viguer JM et $\mathrm{al}^{13}$ and Paul et al.

In the present study 2 cases of Warthin's tumour were encountered on FNAC, and only one case was available for histopathology. This constituted to $3.85 \%$ of all tumours. Grossly, the tumour was capsulated and grey-brown with cut 
surface showing grey white and cystic areas. Microscopy showed typical features of Warthin's tumour, lined by double layer of cells, the outer tall columnar cells and inner cuboidal cells arranged in glandular and papillary formation. Stroma showed abundant lymphoid tissue. Similar observations were made by studies done by Evans and Cruickshank ${ }^{12}$ and Ellis, Auclair and Gnepp. ${ }^{14}$

In the present study, one case of oncocytoma was seen constituting to $1.92 \%$ of all tumours, one case of myoepithelioma was seen constituting to $1.92 \%$ of all tumours. Grossly, the tumour was grey white with cut section showing grey brown areas. Microscopy showed spindle shaped cells with central vesicular nuclei and eosinophilic cytoplasm arranged in interlacing fascicles and solid sheets. Few areas showed hyalinisation. Similar observations were made by studies done by Simpson et al ${ }^{15}$ and Dardick I et al. ${ }^{16}$

In the present study one case of basal cell adenoma [Figure 4] was seen constituting to $1.92 \%$ of all tumours. Grossly the tumour showed irregular, grey white nodular mass. Microscopy showed tumour composed of uniform, small, round to oval basaloid cells with central placed nuclei and scant basophilic cytoplasm arranged in trabecular cords and sheets separated by fibrovascular stroma. Peripheral nuclear palisading was seen in some areas. Similar observations were made by studies done by Evans and Cruickshank, ${ }^{12}$ Dong et al ${ }^{17}$ and Ellis, Auclair and Gnepp. ${ }^{14}$

In the present study, 5 cases of malignant neoplastic lesions were encountered constituting to $9.62 \%$ of total salivary gland lesions; 2 cases of adenoid cystic carcinoma, one case each of mucoepidermoid carcinoma, epithelialmyoepithelial carcinoma and squamous cell carcinoma was noted.

Adenoid cystic carcinoma constitutes to $3.85 \%$ of all tumours and $40 \%$ of malignant tumours which is comparable with the studies done by Ahrnad et $\mathrm{al}^{4}$ and Nascimento et al.18 The present study showed adenoid cystic carcinoma was common in the age group of 45 - 65 years, which is comparable with the studies done by Paul et al. It constituted to $50 \%$ in parotid gland and $50 \%$ in minor salivary gland which is almost comparable with the studies done by Agarwal et al. ${ }^{6}$ Two cases of adenoid cystic carcinoma were encountered in the present study [Figure 5]. Grossly, the tumours were solid and cut surface showing grey white areas with cystic spaces. Microscopy showed tumour composed of small, round to oval cells with hyperchromatic nuclei and scanty cytoplasm arranged in clusters and nests around gland like spaces forming glandular and pseudocystic pattern. Mucinous material was noted in cystic spaces and there was intervening fibrocollagenous stroma. [Figure 6] Similar observations were made by studies done by Evans and Cruickshank ${ }^{12}$ Ellis, Auclair and Gnepp14 and Dutta et al.19 One case of mucoepidermoid carcinoma was encountered in the present study constituting to $1.92 \%$ of all tumours. Mucoepidermoid carcinoma ${ }^{20,21}$ constitutes to $20 \%$ of malignant tumours, which is comparable with the studies done by Ahrnad et al ${ }^{4}$ and Thomas et al. $^{2}$ In the present study, one case of mucoepidermoid carcinoma was found in the age group of 41 - 50 years. It was seen in the parotid gland. Grossly, the tumour was round to oval with cut surface showing cystic spaces. Microscopically, the tumour showed presence of squamous cells, intermediate cells and mucin cells arranged in solid sheets and clusters. Similar observations were made by studies done by Paul et al.14

One case of epithelial-myoepithelial carcinoma 22 was encountered in the present study in the age group of $41-50$ years constituting to $20 \%$ of all malignant tumours. It was seen in the parotid gland. Grossly the tumour was solid, grey white. Microscopy showed bilayered duct like structures. The inner layer is formed by a single row of cuboidal cells with dense, finely granular cytoplasm and central or basal round nucleus. The outer layer shows single or multiple layers of polygonal cells with well-defined borders.

One case of squamous cell carcinoma was encountered in this study in the 61 - 70 year age group in parotid gland constituting to $20 \%$ of all malignant tumours.

In the present study, benign tumours were more common than the malignant tumours and parotid gland was the most common site involved. [Table 8] Comparison of Sensitivity, Specificity and Diagnostic accuracy of salivary gland lesions with other studies showed a sensitivity of $87.50 \%$, specificity of $100 \%$ and Diagnostic accuracy of $88.24 \%$ which is almost comparable with the studies done by Jayaram ${ }^{23}$ and Shintani. ${ }^{24}$

\section{CONCLUSION}

Salivary gland lesions are grouped into non-neoplastic, benign and malignant lesions. Benign tumours are more common than malignant tumours. Major salivary glands are commonly involved. Parotid gland is the most common site of involvement of all salivary gland lesions. Pleomorphic adenoma is the most common benign tumour encountered.

FNAC is a highly reliable technique for pre-operative diagnosis of salivary gland tumours in the hands of experienced pathologists. An accurate cytologic diagnosis can avoid unwarranted surgery. Due to the minimally invasive nature of this technique, FNAC offers valuable information for planning of subsequent therapeutic management. However, there still remain few cases that may be inaccurately diagnosed on cytology due to overlapping features and in these cases histopathology is the only modality for final diagnosis.

\begin{tabular}{|c|c|c|c|}
\hline Age Group & Females & Males & Total \\
\hline (yrs.) & $\mathrm{n}(\%)$ & $\mathrm{n}(\%)$ & $\mathrm{n}(\%)$ \\
\hline $1-10$ & -- & -- & -- \\
\hline $11-20$ & $1(1.92)$ & -- & $1(1.92)$ \\
\hline $21-30$ & $6(11.54)$ & $7(13.46)$ & $13(25.00)$ \\
\hline $31-40$ & $3(5.77)$ & $9(17.31)$ & $12(23.08)$ \\
\hline $41-50$ & $7(13.46)$ & $6(11.54)$ & $13(25.00)$ \\
\hline $51-60$ & $3(5.77)$ & $3(5.77)$ & $6(11.54)$ \\
\hline $61-70$ & $3(5.77)$ & $3(5.77)$ & $6(11.54)$ \\
\hline $71-80$ & $1(1.92)$ & -- & $1(1.92)$ \\
\hline Total & 24 (46.15) & $\mathbf{2 8}(53.85)$ & $\mathbf{5 2}(100.00)$ \\
\hline \multicolumn{4}{|c|}{ Table 1. Age and Sex Distribution of Salivary } \\
Gland Lesions (N = 52) \\
\hline \multicolumn{4}{|c}{} \\
\hline
\end{tabular}

\begin{tabular}{|c|c|}
\hline Lesions & n (\%) \\
\hline Non-Neoplastic Lesions & $04(7.69)$ \\
\hline Benign & $43(82.69)$ \\
\hline Malignant & $05(9.62)$ \\
\hline Total & $\mathbf{5 2}(100.00)$ \\
\hline Table 2. Categorisation of Salivary Gland Lesions (N = 52) \\
\hline
\end{tabular}




\begin{tabular}{|c|c|c|c|c|c|}
\hline \multirow{2}{*}{ Cytodiagnosis } & Parotid & Submandibular & Sublingual & Minor salivary & \\
\hline & Gland & Gland & Gland & Gland & Total \\
\hline & $\mathrm{n}(\%)$ & $\mathrm{n}(\%)$ & $\mathrm{n}(\%)$ & $\mathrm{n}(\%)$ & $\mathrm{n}(\%)$ \\
\hline Pleomorphic Adenoma & $24(55.81)$ & $6(13.95)$ & -- & $6(13.95)$ & $36(83.72)$ \\
\hline Benign cystic lesion & $01(2.33)$ & $01(2.33)$ & -- & -- & $02(4.65)$ \\
\hline Warthin's tumour & $02(4.65)$ & -- & -- & -- & $02(4.65)$ \\
\hline Oncocytoma & $01(2.33)$ & -- & -- & & \\
\hline Benign myoepithelioma & $01(2.33)$ & -- & -- & -- & $01(2.33)$ \\
\hline Basal cell adenoma & $01(2.33)$ & -- & -- & -- & $01(2.33)$ \\
\hline Total & $30(69.77)$ & $7(16.28)$ & -- & $6(13.95)$ & $43(100.00)$ \\
\hline
\end{tabular}

\begin{tabular}{|c|c|c|c|c|c|}
\hline Cytodiagnosis & $\begin{array}{c}\text { Parotid Gland } \\
\mathbf{n}(\%)\end{array}$ & $\begin{array}{c}\text { Submandibular } \\
\text { Gland }\end{array}$ & $\begin{array}{c}\text { Sublingual } \\
\text { Gland }\end{array}$ & $\begin{array}{c}\text { Minor Salivary } \\
\text { Gland n (\%) }\end{array}$ & Total \\
\hline Adenoid cystic Ca & $1(20.00)$ & -- & -- & $1(20.00)$ & $2(40.00)$ \\
\hline Mucoepidermoid Ca & -- & $1(20.00)$ & --- & --- & $1(20.00)$ \\
\hline Epithelial myoepithelial Ca & $1(20.00)$ & -- & -- & -- & $1(20.00)$ \\
\hline Squamous cell Ca & $1(20.00)$ & -- & -- & $1(20.00)$ \\
\hline \multicolumn{2}{|c|}{ Table 4. Cytodiagnosis of Malignant Neoplastic Salivary Gland Lesions (N=05) } \\
\hline
\end{tabular}

\begin{tabular}{|c|c|c|c|c|c|c|c|c|c|c|c|c|}
\hline \multirow[t]{2}{*}{ FNAC } & \multicolumn{12}{|c|}{ Histopathological Diagnosis } \\
\hline & 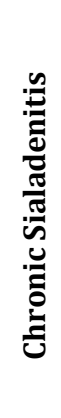 & 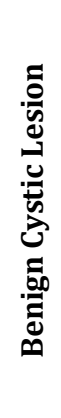 & 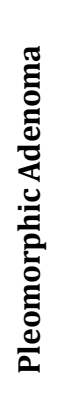 & 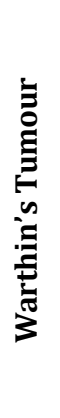 & 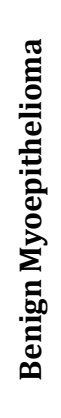 & 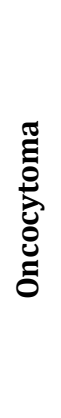 & 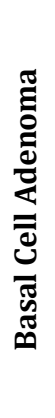 & 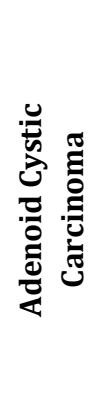 & 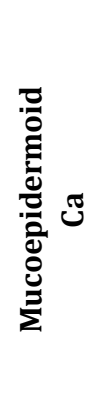 & 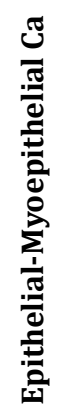 & 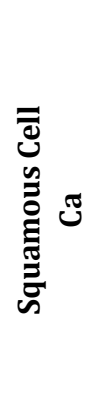 & $\stackrel{\pi}{0}$ \\
\hline Chronic sialadenitis & 2 & -- & 2 & --- & --- & -- & --- & -- & --- & -- & -- & 4 \\
\hline Benign cystic lesion & --- & --- & 2 & $\begin{array}{ll}-- \\
--\end{array}$ & -- & $\begin{array}{ll}-- \\
--\end{array}$ & -- & -- & --- & --- & -- & 2 \\
\hline Pleomorphic adenoma & --- & --- & 19 & --- & -- & --- & -- & -- & --- & --- & -- & 19 \\
\hline Warthin's tumour & --- & --- & -- & 1 & -- & --- & -- & -- & --- & --- & -- & 1 \\
\hline Benign Myoepithelioma & --- & --- & -- & --- & 1 & --- & -- & -- & --- & --- & -- & 1 \\
\hline Oncocytoma (1) & -- & --- & -- & -- & -- & 1 & -- & -- & --- & --- & -- & 1 \\
\hline $\begin{array}{c}\text { Basal Cell } \\
\text { Adenoma (1) }\end{array}$ & --- & --- & -- & --- & -- & --- & 1 & -- & --- & --- & -- & 1 \\
\hline $\begin{array}{c}\text { Adenoid Cystic } \\
\text { Carcinoma (2) }\end{array}$ & - & - & - & - & - & - & - & 2 & - & - & - & 2 \\
\hline $\begin{array}{c}\text { Mucoepidermoid } \\
\mathrm{Ca}(1)\end{array}$ & - & - & - & - & - & - & - & - & 1 & - & - & 1 \\
\hline Epithelial- Myoepithelial Ca(1) & - & - & - & - & - & - & - & - & - & 1 & - & 1 \\
\hline $\begin{array}{l}\text { Squamous cell } \\
\mathrm{Ca}(1)\end{array}$ & - & - & - & - & - & - & - & - & - & - & 1 & 1 \\
\hline Total (34) & 2 & - & 23 & 1 & 1 & 1 & 1 & 2 & 1 & 1 & 1 & 34 \\
\hline & & & & & & & & & & & & \\
\hline
\end{tabular}




\begin{tabular}{|c|c|c|c|}
\hline \multirow[t]{2}{*}{ FNAC Diagnosis } & \multicolumn{3}{|c|}{ Histopathological Diagnosis } \\
\hline & $\begin{array}{c}\text { Positive for } \\
\text { neoplasm }\end{array}$ & $\begin{array}{l}\text { Negative for } \\
\text { neoplasm }\end{array}$ & Total \\
\hline $\begin{array}{c}\text { Positive for } \\
\text { neoplasm }\end{array}$ & $\mathrm{TP}=28$ & $\mathrm{FP}=0$ & 28 \\
\hline Negative for neoplasm & $\mathrm{FN}=04$ & $\mathrm{TN}=02$ & 06 \\
\hline Total & 32 & 02 & 34 \\
\hline \multicolumn{4}{|c|}{ Table 6. The Diagnostic Accuracy of Salivary Gland Lesions in the Present Study $(N=34)$} \\
\hline
\end{tabular}

\begin{tabular}{|c|c|c|}
\hline Series & $\begin{array}{c}\text { Benign } \\
\text { (Average Age in Years) }\end{array}$ & $\begin{array}{c}\text { Malignant } \\
\text { (Average Age in Years) }\end{array}$ \\
\hline Ahrnad et al ${ }^{4}$ & 32.7 & 42.4 \\
\hline Agarwal et al ${ }^{6}$ & 35.0 & 42.0 \\
\hline Vuhahula et al 7 & 33.5 & 43.1 \\
\hline $\begin{array}{c}\text { Krishnarai Subhashraj } \\
\text { et al }{ }^{5}\end{array}$ & 43.0 & 56.0 \\
\hline Present study & 35.0 & 50.0 \\
\hline
\end{tabular}

\begin{tabular}{|c|c|c|c|c|}
\hline Series & $\begin{array}{c}\text { No. of Case } \\
\text { with HPE }\end{array}$ & Sensitivity & Specificity & Diagnostic \\
\hline & Correlation & & & Accuracy \\
\hline Jayaram $^{23}$ & 57 & $80.90 \%$ & $94.30 \%$ & $87.70 \%$ \\
\hline Cristallini EG $^{25}$ & 63 & $97.60 \%$ & $98.45 \%$ & $97.90 \%$ \\
\hline O'Dwyer $^{26}$ & 341 & $73.00 \%$ & $94.00 \%$ & $90.00 \%$ \\
\hline Shintani $^{24}$ & 43 & $88.90 \%$ & $94.10 \%$ & $93.00 \%$ \\
\hline Present study & 34 & $87.50 \%$ & $100.00 \%$ & $88.24 \%$ \\
\hline \multicolumn{2}{|l|}{ Table 8. Comparison of Sensitivity, Specificity and Diagnostic Accuracy of Salivary Gland Lesions with Other Studies } \\
\hline
\end{tabular}

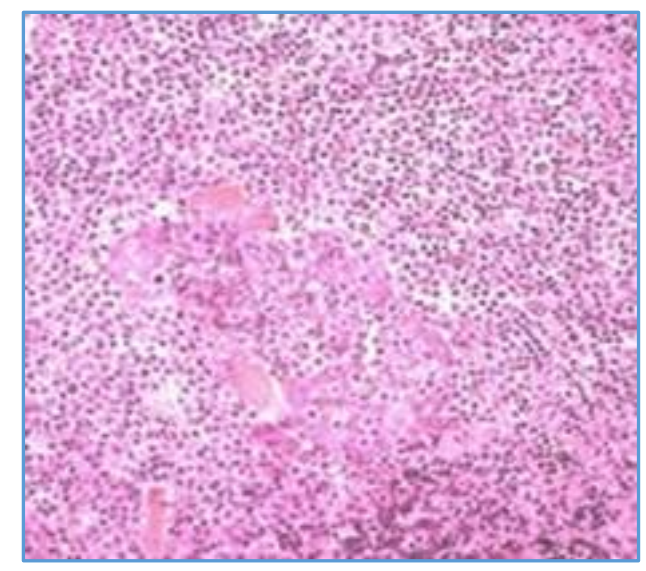

Figure 1. FNAC of Chronic Sialadenitis shows Plenty of Lymphocytes

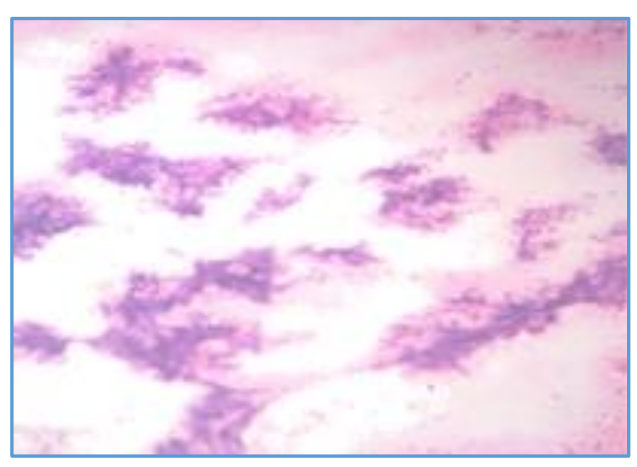

Figure 2. Pleomorphic Adenoma - Cytology showing Myxofibrillary Areas

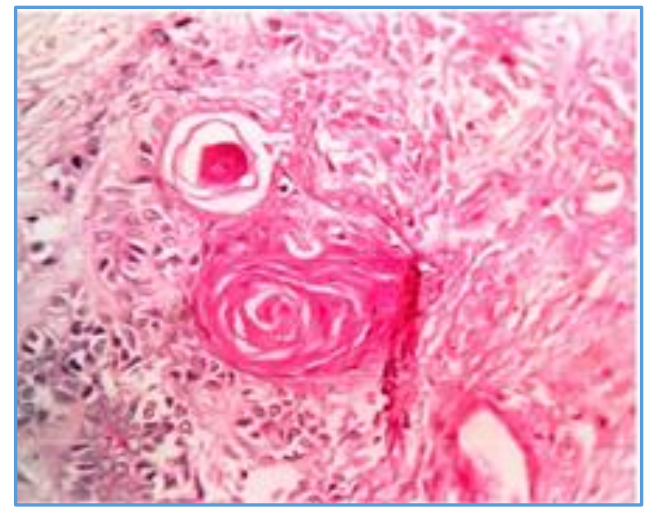

Figure 3. HPE Pleomorphic Adenoma with Squamous Metaplasia

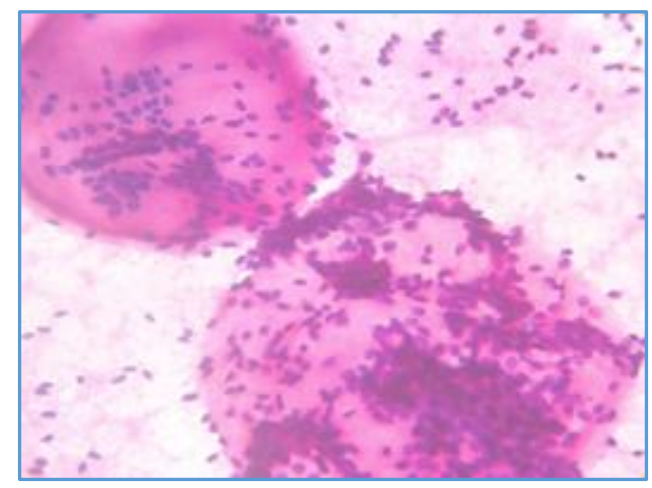

Figure 4. Basal Cell Adenoma - Cytology showing Hyaline Globules and Basaloid Cells 


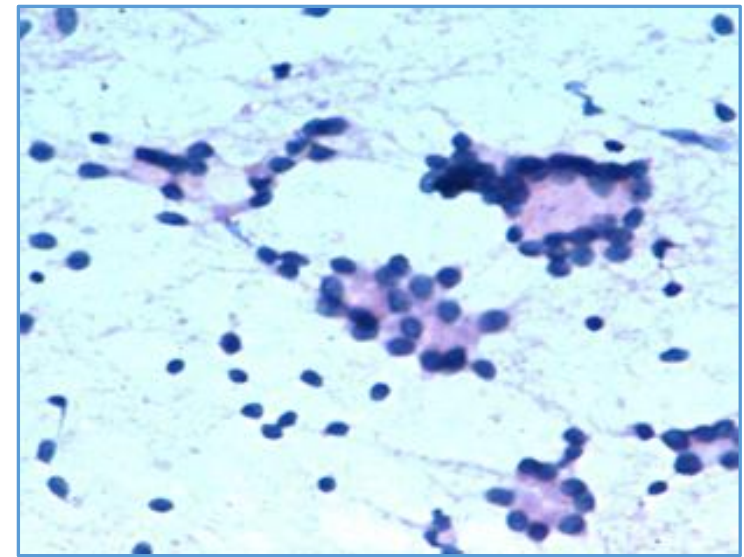

Figure 5. Adenoid Cystic Carcinoma - Cytology

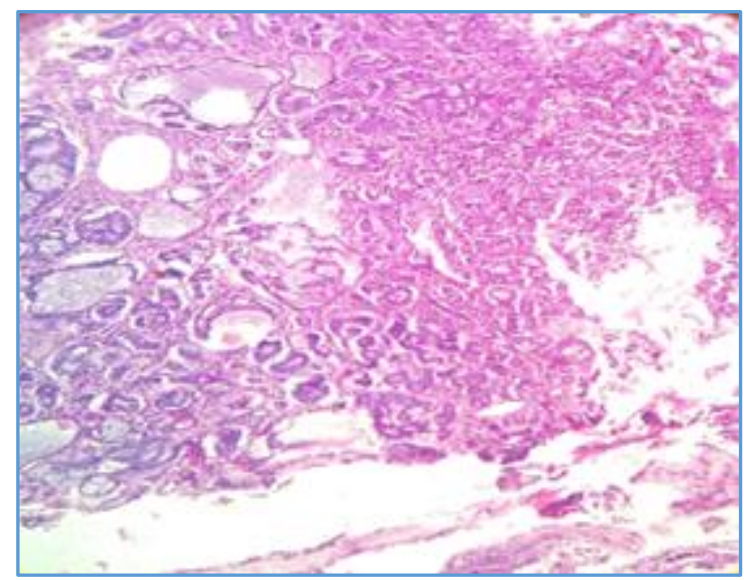

Figure 6. Adenoid Cystic Carcinoma - HPE

\section{REFERENCES}

1. Kasangaki A, Kamulegeya A. Neoplasms of the salivary glands: a descriptive retrospective study of 142 casesmulago hospital Uganda. The Journal of Contemporary Dental Practice 2004;5(3):16-27.

2. Thomas KM, Hutt MS, Borgstein J. Salivary gland tumors in Malawi. Cancer 1980;46(10):2328-34.

3. Gupta SK, Sengupta P, Sarkar SK. Primary tumors of salivary glands. J Ind Med Assoc 1975;65(10):277-8.

4. Ahrnad S, Lateef M, Ahmad R. Clinicopathological study of primary salivary gland tumors in Kashmir. JKPractitioner 2002;9(4):231-3.

5. Subhashraj K. Salivary gland tumors: a single institution experience in India. British Journal of Oral and Maxillofacial Surgery 2008;46(8):635-8.

6. Agarwal RV, Solanki BR, Junnark Sar RV. Salivary gland tumors. Ind Journal of Cancer 1967;4:209-13.

7. Vuhahula EAM. Salivary gland tumors in Uganda: clinical pathological study. African Health Sciences 2004;4(1):15-23.

8. Seth GS, Pandit AA. Diagnosis of salivary gland tumours by FNAC. Bombay Hospital Journal 2007;42(1).

9. Davies JNP, Dodge OG, Burkitt DP. Salivary gland tumors in Uganda. Cancer 1964;17(10):1310-22.
10. Ito FA, Jorge J, Vargas PA, et al. Histopathological findings of pleomorphic adenomas of the salivary glands. Med Oral Pathol Oral Cir Bucal 2009;14(2):E57-61.

11. Nagarkar NM, Bansal S, Dass A, et al. Salivary gland tumors-our experience. Indian Journal of Otolaryngology and Head and Neck Surgery 2004;56(1):31-4.

12. Evans RW, Cruickshank AH. Epithelial tumors of the salivary glands. Vol 1. Philadelphia: WB Saunders 1970.

13. Viguer JM, Vicandi B, Jimenez-Heffernan JA, et al. Fine needle aspiration cytology of pleomorphic adenoma-an analysis of 212 cases. Acta Cytol 1997;41(3):786-94.

14. Ellis GL, Auclair PL, Gnepp DR, et al. Other malignant epithelial neoplasms. Chapter 27, In: Surgical pathology of the salivary glands. Eds: Ellis GL, Auclair PL, Gnepp RD. Vol. 25. Philadelphia: WB Saunders Co. 1991:455-88.

15. Simpson RHW, Jones H, Beasley P. Benign myoepithelioma of the salivary glands. A true entity? Histopathology 1995;27(1):1-9.

16. Dardick I, Thomas MJ, van Nostrand AW. Myoepithelioma new concepts of histology and classification: a light and electron micropic study. Ultrastruct Pathol 1989;13(2-3):187-224.

17. Dong KL, Kye WC, Chung HB, et al. Basal cell adenoma of the parotid gland: characteristics of 2 phase helical computed tomography and magnetic resonance imaging. J Comput Assist Tomogr 2005;29(6):884-8.

18. Nascimento AG, Amarel AL, Prado LA, et al. Adenoid cystic carcinoma of salivary glands: a study of 61 cases with clinicopathologic correlation. Cancer 1986;57(2):312-9.

19. Dutta NN, Baruah R, Das L. Adenoid cystic carcinomaclinical presentation and cytological diagnosis. Indian J of Otolaryngology and Head and Neck Surgery 2002;54(1):62-4.

20. Klijanienko J, Vielh P. Fine needle aspiration of salivary gland lesions IV. Review of 50 cases of mucoepidermoid carcinoma with histopathology correlation. Diagn Cytopathol 1997;17(5):347-52.

21. Ghosh-Laskar S, Murthy V, Wadasadawala T, et al. Mucoepidermoid carcinoma of the parotid gland: factors affecting outcome. Head Neck 2011;33(4):497-503.

22. Arora VK, Misra K, Bhatia A. Cytomorphologic features of the rare epithelial-myoepithelial carcinoma of the salivary gland. Acta Cytol 1990;34(2):239-42.

23. Jayaram G, Dashini M. Evaluation of fine needle aspiration cytology of salivary glands: an analysis of 141 cases. Malaysian Journal of Pathology 2001;23(2):93100.

24. Shintani S, Matsura H, Hasegawa. Fine needle aspiration of salivary gland tumors. Int J Oral Maxillofac Surg 1997;26(4):284-6.

25. Cristallini EG, Ascani S, Farabi R, et al. Fine needle aspiration biopsy of salivary gland, 1985-1995. Acta Cytol 1997;41(5):1421-5.

26. O'Dwyer P, Farr WB, James AG, et al. Needle aspiration biopsy of major salivary glands tumors. Its Value. Cancer 1986;57(3):554-7. 